\title{
Аналіз технологічних властивостей робочих органів культиватора передпосівного поверхневого обробітку ґрунту і удосконалення стрілчастої лапи
}

\author{
Г.В. Фесенко ${ }^{1}$, М.А. Жмуренко \\ Луганський національний аграрний університет \\ (м. Старобільськ, Україна) email: ${ }^{1}$ fesenko1491@ukr.net
}

\begin{abstract}
Одним із напрямків інтенсифікації сільськогосподарського виробництва $є$ підвищення рівня механізації виробничих процесів в землеробстві за рахунок застосування більш досконалих технічних засобів. Це в повній мірі відноситься до передпосівного поверхневого обробітку ґрунту, спрямованого на збереження вологи на глибині посіву і створення умов його рихлення без руйнування структури ґрунту. В результаті проведеного аналізу, установлено, що на початковій стадії переміщення в ґрунті стрілчастої лапи відбувається ущільнення підрізаного пласта з наступним зрушенням і кришенням в площині, розташованій під нахилом до горизонту. Подальше переміщення пласта по плоскій полиці робочого органу відбувається без рихлення до падіння з його обрізу, під час якого перемішується верхній сухий із нижнім вологим шаром ґрунту. Крім того, після сходу підрізаного пласта з крил стрілчастої лапи і удару його ґрунтових агрегатів об ґрунтову підошву утворюється переподрібнена і пиловидна фрракція, яка не являється агротехнічно-цінною для ґрунту. що погіршує його структурний склад. Аналітичні дослідження також показали, що підвищити ступінь кришення культиватором ґрунту і зменшити при цьому утворення переподрібненої фракції можливо, якщо в стрілчастій лапі полиці виконати випуклими у верхньому напрямку, при цьому кривизна випуклості повинна змінюватись з віддаленням від ріжучої кромки і обрізу полиці. Установлено, що ріжучу кромку і обріз полиці лапи слід розташувати в одній горизонтальній площині. Виконана в такому вигляді стрілчаста лапа створює умови подальшого кришення підрізаного ним пласта ґрунту під час його руху по крилах лапи і поступове сходження з них без падіння, що запобігає взаємне переміщення оброблюваних шарів ґрунту з виносом на поверхню вологого шару $\mathrm{i}$ утворення переподрібненої пиловидної фракції. яка погіршує структурний склад ґрунту.
\end{abstract}

Ключові слова: стрілчаста лапа, передпосівний обробіток, культивація, полиця, пласт, структура, грунт, розпушування, кришення, культиватор.

Актуальність проблеми. В системі обробітку ґрунту провідне місце займає поверхневий обробіток, який створює кращі умови для водопроникнення та збереження вологи в ґрунті, а також відтворення його родючості. В залежності від польових умов, поверхневий обробіток ґрунту виконують в основному у вигляді лущення, культивації, боронування. При цьому культивація ґрунту займає особливе місце в технологічних процесах вирощування сільськогосподарських культур, в яких, поряд з іншими робочими органами для догляду за парами, передпосівної культивації і міжрядного обробітку ґрунту, використовують підрізувальні робочі органи: стрілчасті, плоскорізальні та стрілчасті універсальні лапи різного конструктивного виконання. Разом з цим передпосівною культивацією Ґрунту передбачено дотримання ряду агротехнічних вимог, виконання яких забезпечує максимальну реалізацію біопотенціалу культури, що планується вирощувати на даному полі. До таких вимог відноситься рихлення ґрунту із створенням розпушеного дрібно грудочкува- того структурного шару і рівною поверхнею для зменшення випаровування вологи, повне підрізання бур'янів і створення посівного ложе для кращого контакту насіння з ґрунтом. [1]. Крім того, під час рихлення ґрунту робочі органи культиватора не повинні виносити на поверхню нижнього вологого шару ґрунту, що пов'язано з проростанням насіння, якому необхідно спочатку увібрати необхідну кількість вологи, наприклад, для насіння пшениці 46\% води від своєї маси. При недостатній вологості ґрунту на глибині посіву проростання насіння затримується, що призводить до зниження польової схожості [2]. Слід відмітити, що при передпосівному поверхневому обробітку ґрунту серійні культиватори, основними робочими органами яких $є$ стрілчасті лапи, недостатньо кришать поверхневий шар ґрунту, перемішують між собою його шари, внаслідок чого виноситься на поверхню нижній вологий шар ґрунту. [3]. При цьому, падіння підрізаного пласта ґрунту із заднього обрізу крил лапи створює умови ударного руйнування його агрегатів 3 утворенням 
переподрібненої і пиловидної фрракції, яка не $є$ агротехнічно-цінною для ґрунту [4]. Виходячи із цього підвищення якості передпосівного обробітку ґрунту за рахунок удосконалення стрілчастих лап культиватора являється актуальним.

Аналіз останніх досліджень та публікацій. Результати аналітичних досліджень показали, що основним завданням культиваторів при передпосівному поверхневому обробітку ґрунту $\epsilon$ створення сприятливих умов для якісного посіву насіння на задану глибину із загортанням його вологим шаром. Слід відмітити, що вирішенню питань вдосконалення культиваторних робочих органів присвячені провідні наукові роботи В.П. Горячкіна, П.М. Василенка, П.Т. Бабія, Г.Н. Синеокова, І.М. Панова, В.А. Сакуна, Л.В. Гячева, О.А. Сизова, А.С. Найденова та інших, в яких приведені важливі результати досліджень культиваторів і технологічних процесів передпосівного поверхневого обробітку ґрунту.

Разом з цим, аналітичні дослідження проведення культиваторами передпосівного поверхневого обробітку ґрунту показали, що на показники його кришення в значній мірі впливають конструктивні елементи стрілчастих лап, а саме форма поверхні крил і їх кут нахилу до напрямку обробітку ґрунту, так як саме вони обумовлюють якісні показники роботи [5]. Разом з цим відомо, що процес деформації і кришення поверхневого пласта ґрунту культиватором із серійними стрілчастими лапами починається при його підрізанні. Подальше переміщення підрізаного пласта ґрунту відбувається по його плоских полицях крил, які не створюють сприятливі умови для продовження його кришення [6].

Крім того, при сходженні пласта ґрунту із заднього обрізу полиці крил під дією сили тяжіння, відбувається його падіння із-за зміщення по висоті заднього обрізу крила відносно його ріжучої кромки. При цьому відбувається переміщення шарів пласта ґрунту із виносом вологого шару на поверхню, а на його місце переміщується поверхневий шар пониженої вологості, що погіршує умови проростання насіння, висіяного в такий ґрунт [7]. Установлено, що при падінні пласта ґрунту на поверхню ґрунту відбувається ударне руйнування його ґрунтових агрегатів на частки 3 утворенням переподрібненої і пиловидної фрракції, яка погіршує структуру ґрунту [8] (рис.1). При цьому, потенціальна енергія ґрунтових агрегатів при падінні пласта переходить у кінетичну енергію, яка витрачається на їх ударне руйнування. Кінетична енергія виділеного елемента в такому пласту ґрунту дорівнює сумі кінетичних енергій його ґрунтових агрегатів $\left(W_{\kappa}\right)$, величина яких визначається за наступною залежністю [9]:

$$
W_{\kappa}=\frac{1}{2} \int_{m} v_{\kappa}^{2} d m
$$

де $d m$ - маса частки ґрунтового агрегату, ке; $v_{\kappa}$ - кінцева швидкість руху ґрунтового агрегату, м/c; $m$ - маса ґрунтового агрегату, ке.

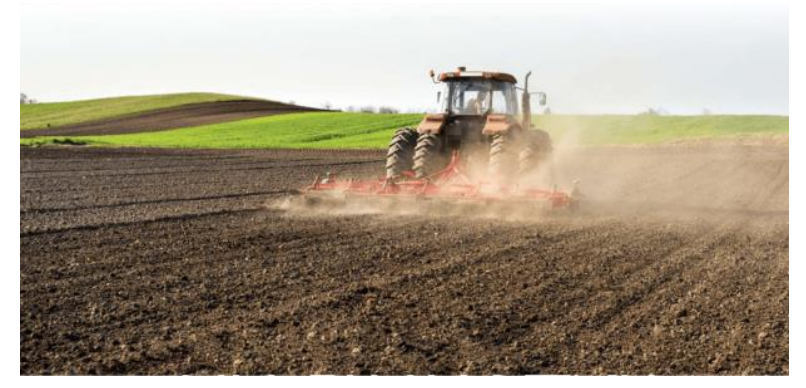

Рис. 1 - Робота культиватора із стрілчастими лапами на передпосівному поверхневому обробітку ґрунту

Кінцеву швидкість $\left(v_{\kappa}\right)$ ґрунтового агрегату за умови не значимого впливу повітря при його падінні з обрізу крила лапи, розташованого відносно поверхні ґрунту на висоті $(h)$, визначається за наступною формулою:

$$
v_{\kappa}=\sqrt{2 \cdot g \cdot h},
$$

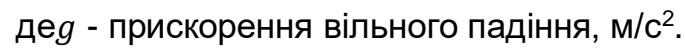

В результаті недостатнього ступеня кришення поверхневого ґрунту стрілчастими лапами із плоскою поверхнею крил і утворення при цьому переподрібненої пиловидної фракції, застосування їх в культиваторі для передпосівного поверхневого обробітку ґрунту, не забезпечує в повній мірі виконання агротехнічних вимог, що погіршує умови проростання висіяного в такий ґрунт насіння [10].

Поряд із використанням стрілчастих лап із плоскою поверхнею крил, для передпосівного обробітку ґрунту застосовують рихлячі робочі органи із вгнутою поверхнею, кривизна яких залишається сталою по їх висоті [11]. Під час роботи культиватора $з$ такими робочими органами, деформація із кришенням пласта поверхневого ґрунту відбувається переважно при його підрізанні. Рихлення підрізаного пласта при подальшому переміщенні по вгнутій поверхні робочого органу призупиняється із-за сталої кривизни його робочої поверхні. Крім того, в результаті падіння пласта ґрунту при сході з такого робочого органу відбувається взаємне переміщення його шарів $з$ виносом на поверхню вологого шару, при цьому в результаті ударного руйнування пласта об підошву ґрунту утворюється переподрібнена і пиловидна фрракція, що погіршує структуру ґрунту.

До ґрунтообробних знарядь, що призначені для поверхневого рихлення ґрунту, в тому числі і передпосівної культивації, відноситься робочий орган, в якому поверхня лапи утворена вгнутими 
і випуклими ділянками у вигляді циліндричних поверхонь [12]. Під час роботи ґрунтообробної машини з таким робочим органом, рух підрізаного і деформованого пласта ґрунту по вгнутій робочій поверхні відбувається з його об'ємним ущільненням. 3 початком переміщення пласта ґрунту на випуклу робочу поверхню лапи, в ньому утворюються тріщини, які сприяють його розущільненню. Разом $з$ цим, подальше розущільнення пласта 3 переміщенням по випуклій робочій поверхні лапи робочого органу не відбувається із-за сталої кривизни її циліндричної поверхні. Після сходу пласта ґрунту із такого робочого органу, із-за того, що задній обріз полиці зміщений по висоті відносно ріжучої кромки лапи, відбувається його падіння, внаслідок чого переміщуються його шари 3 виносом на денну поверхню вологого шару ґрунту і утворюється переподрібнена пиловидна фракція, що погіршує умови проростання насіння висіяного в такий ґрунт.

Відповідною здатністю рихлення ґрунту наділена стрілчаста лапа культиватора для поверхневого обробітку ґрунту, в якій робоча поверхня крил виконана криволінійною з ділянками у вигляді циліндричних і конічних поверхонь, при цьому робоча поверхня кожного крила містить окрім вгнутої ділянки з циліндричною поверхнею, також випуклу з поверхнею у вигляді зрізаного конуса [13]. Під час передпосівного поверхневого обробітку ґрунту культиватором з таким робочим органом, переміщення підрізаного пласта по вгнутій ділянці призводить до його ущільнення, що погіршує умови розущільнення і кришення пласта при переміщенні на випуклу ділянку робочого органу, при цьому, конусні виступи на крилах робочого органу кришать тільки окремі ділянки підрізаного пласта ґрунту. Крім того, під час падіння пласта ґрунту із заднього обрізу полиці, зміщеній по висоті відносно її ріжучої кромки, його нижній вологий шар ґрунту і верхній шар з пониженою вологістю перемішуються між собою, знижуючи тим самим його вологість на глибині посіву. Разом з цим в результаті удару ґрунтових агрегатів пласта об підошву ґрунту, утворюється переподрібнена і пиловидна фракція, погіршуючи структурний склад ґрунту, а отже і умови проростання насіння висіяного в такий ґрунт.

Метою роботи $€$ підвищення ефективності застосування культиватора із стрілчастими лапами при передпосівному поверхневому обробітку ґрунту.

Відповідно до мети в роботі поставлена задача: на основі проведених аналітичних досліджень обґрунтувати стрілчасту лапу культиватора з підвищеною ефективністю передпосівного обробітку ґрунту, а саме підвищення ступеня кришення оброблюваного шару ґрунту з одночасним зменшенням переподрібненої і пиловидної фрракції.
Поставлена задача вирішується, якщо у стрілчастій лапі культиватора, яка містить крила у вигляді полиці з випуклостями на їх робочій поверхні, випуклості полиць виконати звернутими вгору від носка лапи до кінця крила. При цьому кривизну опуклості виконати неперервно змінною у верхньому напрямку з віддаленням від ріжучої кромки і обрізу полиці. Крім того, ріжучу кромку і обріз кожної полиці слід розташувати в горизонтальній площині, при цьому коефіцієнт тертя обрізу полиці по ґрунту не повинен перевищувати коефіцієнт його внутрішнього тертя [14]. Такими властивостями наділена стрілчаста лапа культиватора для передпосівного поверхневого обробітку ґрунту, схема якої показана ниже (рис. 1).

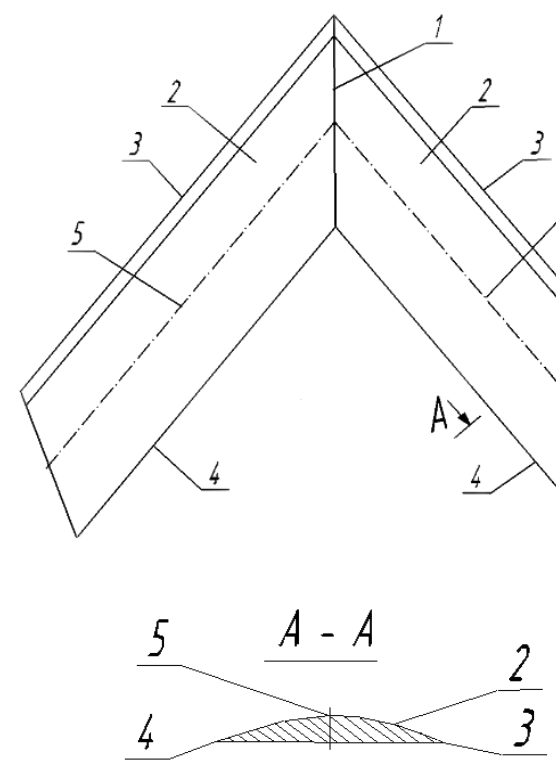

Рис.1. Схема стрілчастої лапи культиватора передпосівного поверхневого обробітку ґру-

нту: 1 - крила лапи; 2 - полиця крила;

3 - ріжуча кромка лапи; 4 -обріз полиці; 5 -випуклість полиці.

Під час роботи культиватора на передпосівному поверхневому обробітку ґрунту із такою стрілчастою лапою, кожна полиця 2 крил 1 своєю кромкою 3, підрізає пласт ґрунту з розущільненням і спрямовує його на випуклість 5, яка звернута вгору від носка лапи до кінця кожного крила 1. При цьому випуклість 5 виконана параболічної форми, яка характеризується неперервною зміною кривизни опуклості у верхньому напрямку 3 віддаленням від ріжучої кромки 3 і обрізу 4 полиці 2 [15]. При переміщенні підрізаного ріжучою кромкою 3 пласта ґрунту по випуклості 5 у верхньому напрямку, в результаті неперервної зміни кривизни її випуклості, під дією деформацій згину та зсуву відбувається безперервне утворення тріщин в пласту ґрунту, які спричинюють його 
розущільнення і наступне кришення переважно на частки структурних розмірів. Подальше переміщення пласта ґрунту по випуклості 5 відбувається в нижньому напрямку по неперервно змінній її кривизні. При цьому процес розущільнення пласта ґрунту і його кришення на структурні частки відбувається за рахунок кінетичної енергії пласта і продовжується до його сходу з обрізу 4 полиці 2 на поверхню ґрунту. Разом з цим, розташування ріжучої кромки 3 в одній горизонтальній площині з обрізом 4, коефіцієнт тертя якого по ґрунту не перевищує його коефіцієнта внутрішнього тертя, забезпечує плавний схід пласта ґрунту 3 крил 1 стрілчастої лапи, що унеможливлює його падіння. Внаслідок цього при передпосівному поверхневому обробітку ґрунту його нижній вологий шар зберігається на глибині загортання насіння і упереджується створення умов для руйнування ґрунту з утворенням переподрібненої і пиловидної фракції.

Висновок. В результаті аналізу стану питання технології передпосівного поверхневого обробітку ґрунту і технічних засобів для його здійснення установлено, що агротехнічні показники, які стосуються при цьому, а саме якісне кришення ґрунту і збереження його структурного складу, не виконуються в повній мірі. Причиною цьому, як виявилось, є непристосованість відомих стрілчастих робочих органів, якими в більшості випадків, обладнують культиватори, якісно виконувати передпосівний обробіток, а саме, сходження підрізаного пласта ґрунту з обрізу крил таких робочих органів відбувається з падінням, внаслідок чого переміщуються його шари із виносом на поверхню його вологого шару і під дією кінетичної енергії відбувається ударне руйнування його ґрунтових агрегатів з утворенням переподрібненої і пиловидної фрракції, що погіршує умови проростання насіння висіяного в такий ґрунт. Для підвищення якісних показників передпосівного поверхневого обробітку ґрунту культиватором із стрілчастими лапами необхідно їх крила виконати випуклими вгору, при цьому кривизну опуклості виконати неперервно змінною у верхньому напрямку з віддаленням від ріжучої кромки і обрізу полиці крил, а ріжучу кромку і обріз кожної полиці розташувати в горизонтальній площині.

Внаслідок цього під час роботи культиватора відбувається плавний схід пласта із такої стрілчастої лапи, що не уможливлює його падіння, при цьому, кінетична енергія при сході з крил витрачається на утворення часток переважно структурного складу.

Запровадження у сільськогосподарське виробництво культиватора з такими стрілчастими лапами дозволить підвищити його ефективність при передпосівному поверхневому обробітку ґрунту за рахунок підвищення ступеня кришення оброблюваного шару ґрунту на структурні частки з одночасним зменшенням переподрібненої і пиловидної фракції, що створить сприятливі умови для проростання насіння, висіяного в такий ґрунт.

\section{Література}

1. Агротехнічні вимоги та оцінка якості обробітку ґрунту: навчальний посібник / М.С. Чернілевський, Ю.А. Білявський, Р.Б. Кропивницький, Л.І. Ворона, - Житомир : ЖНАУ, 2009. - 89 с.

2. Петриченко В.Ф., Лихочвор В.В. Рослинництво. Нові технології вирощування польових культур: підручник. - 5-те вид., виправ., допов. Львів: НВФ "Українські технології", 2020. - 806 с.

3. Демидов С. Особливості конструкції та порівняльні характеристики культиваторів суцільного обробітку ґрунту вітчизняного виробництва /С. Демидов, М. Стародубцева, О. Ревтьо // Техніко-технологічні аспекти розвитку та випробування нової техніки і технологій для сільськогосподарського виробництва України: зб. наук. пр. УкрНДІПВТ ім. Л. Погорілого, Дослідницьке, 2015. - № 19 (33) - С. 183-195.

4. Шкварук М.М., Делеменчук М.І. Ґрунтознавство. - К.: Вища школа, 1976. - 320 с.

5. Войтюк Д.Г., Яцун С.С., Довжик М.Я. Сільськогосподарські машини. Основи теорії та розрахунку. Суми, ВДТ: Універсальна книга, 2006. - C. 95 - 103.

6. Синеоков Г.Н., Панов И.М. Теория и расчет почвообрабатывающих машин. М.: Машиностроение, 1977. - С.53 - 60.

7. Василенко П.М., Бабий П.Т. Культиваторы. К.: УАСХН, 1961. - С.13.

8. Конструкція, розрахунок і виробництво сільськогосподарських машин. Конспект лекцій для студентів спеціальності “Машини та обладнання сільськогосподарського виробництва" (6.090200) машинобудівного фракультету денної та заочної форм навчання. - Цизь І.Є. - Луцьк: ЛНТУ, 2008. - 140 с.

9. Яворский Б.М., Детлаф А.А. Справочник по физике / Б.М. Яворский, А.А. Детлаф. Л.: Наука, 1965. - C.58.

10. Технологія виробництва продукції рослинництва. Ч.2/ Мельник С.І., Муляр О.Д., Кочубей М.Й., Іванцов П.Д. - К.: Аграрна освіта, 2010. $-405 \mathrm{c}$.

11. Василенко П.М., Бабий П.Т. Культиваторы. К.: УАСХН, 1961. - С. 22 - 24.

12. Патент SU 1052175, 1983.

13. Патент РФ 2070363, 1996.

14. Стрілчаста лапа культиватора : пат. 121005 Україна : МПК А01В 15/02. № a 2019 01585 ; заявл. 18.02.2019 ; опубл. 10.03.2020, Бюл. № 5. 
15. Выгодский М.Я. Справочник по высшей математике / М.Я. Выгодский. М.: Наука, 1975. $-872 \mathrm{c}$

\section{References}

1. Chernilevskyi, M.S. et al. (2009) Agrotekhnichni vymogy ta otsinka yakosti obro-bitku gruntu: navchalnyi posibnyk. Zhytomyr: ZhNAU. $89 \mathrm{p}$.

2. Petrychenko, V.F. and Lykhochvor, V.V. (2020) Roslynnytstvo. Novi tekhnologii vyroshchuvannia poliovykh kultur: pidruchnyk. 5th ed. Lviv: NVF "Ukrayinski tekhnologii." 806 p.

3. Demydov, S., Starodubtseva, M. and Revtio, O. (2015) "Osoblyvosti konstruktsii ta porivnialni kharakterystyky kultyvatoriv sutsilnogo obrobitku gruntu vitchyznianogo vyrobnytstva," Tekhnikotekhnologichni aspekty rozvytku ta vyprobuvannia novoii tekhniky $i$ tekhnologii dlia silskogospodarskogo vyrobnytstva Ukrayiny: zb. nauk. pr. UkrNDIPVT im. L. Pogorilogo. Doslidnytske, (19(33)), pp. 183 - 195.

4. Shkvaruk, M.M. and Delemenchuk, M.I. (1976) Gruntoznavstvo. Kyiv: Vyshcha shkola. 320 p.

5. Voitiuk D.G., Yatsun S.S., Dovzhyk M.Ya. Silskogospodarski mashyny. Osnovy teorii ta rozrakhunku. Sumy, VDT: Universalna knyga, 2006. pp. 95 - 103.
6. Syneokov G.N., Panov I.M. Teoriia I raschet pochvoobrabatyvaiushchikh mashin. M.: Mashinistroieniie, 1977. - pp. 53-60.

7. Vasilenko P.M., Babii P.T. Kultivatory. K.: UASKhN, 1961. -13 p.

8. Konstruktsiia, rozrakhunok I vyrobnytstvo silskogospodarskykh mashyn. Konspekt lektsii dlia studentiv spetsialnosti "Mashyny ta obladnannia silskogospodarskogo vyrobnytstva" (6.090200) mashynobudivnogo fakultetu dennoyi ta zaochnoyi form navchannia. - Tsyz I.Ye. - Lutsk: LNTU, 2008. $-140 \mathrm{p}$.

9. Yavorskyi B.M., Detlaf A.A. Spravochnik po fizike / B.M. Yavorskyi, A.A. Detlaf. L.: Nauka, 1965. - $58 \mathrm{p}$.

10. Tekhnologiia vyrobnytstva produktsii roslynnytstva. Ch.2 / Melnyk S.I., Muliar O.D., Kochubei M.Y., Ivantsov P.D. - K.: Agrarna osvita, 2010. - 405 p.

11. Vasilenko P.M., Babii P.T. Kultivatiry. K.: UASKhN, 1961. - pp. 22-24.

12. Patent SU 1052175, 1983.

13. Patent RF 2070363, 1996.

14. Strilchasta lapa kultivatora: pat. 121005 Ukrayina: MPK A01B 15/02. № a 2019 01585; zayavl. 18.02.2019; opubl. 10.03.2020, Bul. № 5 .

15. Vygodskii M.Ya. Spravochnik po vysshei matematike / M.Ya. Vygodskii. M.: Nauka, 1975. $872 \mathrm{p}$.

\section{Аннотация}

\section{Анализ технологических свойств рабочих органов культиватора предпосевной поверхностной обработки почвы и усовершенствование стрельчатой лапы}

\section{Г.В. Фесенко, М.А. Жмуренко}

Одним из направлений интенсификации сельскохозяйственного производства является повышение уровня механизации производственных процессов в земледелии за счет применения более совершенных технических средств. Это в полной мере относится к предпосевной поверхностной обработки почвы, направленной на сохранение влаги на глубине посева и создание условий для его рыхления без разрушения структуры почвы. В результате проведенного анализа, установлено, что на начальной стадии перемещения в почве стрельчатой лапы происходит уплотнение подрезающего пласта со следующим сдвигом и крошение в плоскости, расположенной под наклоном к горизонту. Последующее перемещение пласта по плоской полке рабочего органа происходит без рыхления до падения из его обреза, во время которого перемешивается верхний сухой с нижним влажным слоем почвы. .Кроме этого, после схода подрезаного пласта из крыльев стрельчатой лапы и удара его ґрунтовых агрегатов о ґрунтовую подошву образуется переизмельченная и пылевидная фрракция, которая не представляется агротехническо-ценной для почвы. что ухудшает его структурный состав. Аналитические исследования также показали, что повысить степень крошения культиватором почвы и уменьшить при этом образование переизмельченной фракции возможно, если в стрельчатой лапе полки выполнить выпуклыми в верхнем направлении, при этом кривизна выпуклости должна изменяться с отдалением от режущей кромки и обрезу полки. Установлено, что режущую кромку и обрез полки лапы следует расположить в одной горизонтальной плоскости. Выполнена в таком виде стрельчатая лапа создает условия последующего крошения подрезаного им пласта почвы во время его движения по крыльям лапы и постепенное схождение из них без падения, что предотвращает взаимное перемещение обрабатываемых слоев почвы с выносом на поверхность влажного слоя и образование переизмельченной пылевидной фракции, которая ухудшает структурный состав почвы.

Інженерія природокористування, 2020, №1(15), с. 89 - 94 Engineering of nature management, 2020, \#1(15), p. 89 - 94 
Ключевые слова: стрельчатая лапа, предпосевное возделывание, культивация, полка, пласт, структура, почва, рыхление, крошение, культиватор.

\section{Abstract \\ Analysis of cultivator working bodies technological properties of pre-sowing soil surface treatment and cultivator sweep improvement}

\section{G.V. Fesenko, N.A. Zhmurenko}

One of the directions of agricultural production intensification is to increase the level of production processes mechanization in agriculture through the use of more advanced technical means.

This fully applies to pre-sowing surface cultivation of the soil, aimed at preserving moisture in the soil and creating conditions for uniform seeding of seeds to a given depth.

As a result of the analysis it is found that at the initial stage of cultivator sweep movement in the soil the undercut layer is compacted with the next shift and crumbling in a plane located at an angle to the horizon.

Subsequent movement of the layer on a flat shelf of the working body occurs without loosing until it falls from its edge during which the upper dry with the lower moist soil layer is mixed.

Besides after the undercut layer has descended from the wings of the cultivator sweep and the impact of its soil aggregates on the soil sole a crushed and dusty fraction is formed which does not seem agrotechnically valuable for the soil and it worsens its structural composition.

Analytical studies have also shown that it is possible to increase the degree of crumbling the soil by the cultivator and reduce the formation of the overground fraction if in the cultivator sweep the shelves are convex in the upper direction, while the curvature of the bulge should change with distance from the cutting edge and the edge of the shelf.

It is found that the cutting edge and the edge of the sweep should be located in one horizontal plane.

The cultivator sweep made in this form creates the conditions for the subsequent crumbling of the soil layer cut by it during its movement along the wings of the sweep and its gradual descent from them without falling, which prevents the reciprocal movement of cultivated soil layers from being transported to the wet layer surface and the formation of overground dust fraction, which worsens the structural soil composition.

Keywords: cultivator sweep, pre-sowing cultivation, cultivation, shelf, layer, structure, soil, loosing, crumbling, cultivator.

\section{Бібліографічне посилання/ Bibliography citation: Harvard}

Fesenko, G.V. and Zhmurenko, N.A. (2020) Analysis of cultivator working bodies technological properties of pre-sowing soil surface treatment and cultivator sweep improvement Engineering of nature management, (1(15), pp. 89 - 94.

Подано до редакції / Received: 02.02.2020 